\title{
STUDI PENGEMBANGAN KEMAMPUAN SUMBER DAYA MANUSIA DALAM PELAYANAN PUBLIK DI KANTOR PELAYANAN TERPADU KABUPATEN JENEPONTO
}

\author{
Akhmad \\ Dosen Universitas Perjuang Republik Indonesia (UPRI) Makassar
}

\begin{abstract}
ABSTRAK
Saat ini masih sering dijumpai adanya keluhan masyarakat terhadap kemampuan pelayanan yang diberikan oleh aparatur, baik terhadap prosedur-prosedur pelayanan, lamanya pelayanan serta keputusan-keputusan dalam pelayanan yang tidak dapat dilakukan secara efisien dan efektif. Oleh sebab itu penelitian ini penelitian ini adalah untuk mengetahui Untuk mengetahui pelayanan IMB yang diberikan birokrasi di Kantor Pelayanan Terpadu Kabupaten Jeneponto, menganalisis kemampuan sumber daya manusia dalam memberikan pelayanan IMB di Kantor Pelayanan Terpadu Kabupaten Jeneponto serta untuk mengetahui Masalah-masalah apa yang dihadapi pelayanan IMB di Kantor Pelayanan Terpadu Kabupaten Jeneponto.Tipe penelitian yang digunakan adalah metode kualitatif, pengumpulan data dilakukan secara trianggulasi (gabungan), data yang dihasilkan bersifat deskriptif. Hasil penelitian menunjukkan bahwa Sumber daya manusia dalam hal ini aparatur dalam pemberian pelayanan kepada masyarakat di Kantor Pelayanan Terpadu Kabupaten Jeneponto memiliki kualitas yang cukup memadai, yang ditandai dengan tingkat pendidikan umumnya S-1 dan S-2, serta didukung oleh pengembangan pengetahuan dan keterampilan baik melalui pendidikan lanjutan maupun pendidikan dan latihan.
\end{abstract}

Kata Kunci: Sumber Daya Manusia, Pelayanan Publik, Pelayanan Terpadu

\section{PENDAHULUAN}

Seiring dengan reformasi nasional, yang telah bergulir sejak tahun 1998 yang ditandai dengan lahirnya berbagai regulasiregulasi baru dalam sistem pemerintahan dan pembangunan nasional, maka juga telah diikuti pada upaya-upaya pembinaan dan pengembangan sumber daya aparatur, yang dimaksudkan agar seluruh sumber daya aparatur dapat melaksanakan tugastugasnya dengan sebaik-baiknya, terutama dalam memberikan pelayanan kepada masyarakat.

Kegiatan pelayanan pada masyarakat, maka organisasi pelayanan publik seringkali dihadapkan pada masalah-masalah prioritas dalam memberikan pelayanan, sehingga mekanisme pelayanan kadang tidak sesuai dengan urutan-urutan pelayanan itu sendiri. Di samping itu aspek manajemen belum sepenuhnya berjalan sesuai dengan prinsip-prinsip managerial, terutama dilihat dari mekanisme fungsi-fungsi pada masing-masing unit kegiatan dalam organisasi tersebut, bahkan sering terjadi adanya keluhan dari masyarakat, karena rendahnya koordinasi pelayanan.

Kualitas pelayanan hanya dapat diukur pada sejauh mana memberikan pelayanan yang memadai, yaitu menyelesaikan job order berdasarkan prinsip ketepatan waktu, ketepatan prosedur dan kepastian biaya, serta kualitas layanan yang memuaskan. Salah satu unit kerja pemerintahan di Kabupaten Jeneponto, yang memiliki peran strategis 
dalam memberikan pelayanan kepada masyarakat, adalah pelayanan Izin Mendirikan Bangunan di Dinas Pemukiman, Perumahan dan Kebersihan Kabupaten Jeneponto.

$$
\text { Pelayanan Izin Mendirikan }
$$

Bangunan adalah layanan yang bersifat kewenangan pemerintah, di mana Izin Mendirikan Bangunan (IMB) hanya dapat diterbitkan oleh Pemerintah Daerah berdasarkan Peraturan PerundangUndangan yang berlaku. Kewenangan ini mengandung fungsi pemerintahan, yaitu fungsi pengaturan dan pengendalian, di mana pemerintah dalam proses memberikan IMB kepada masyarakat harus memperhatikan kepentingan yang terkait dengan lingkungan pemukiman pada lokasi yang akan diberikan IMB tersebut, oleh sebab itu dalam proses pemberian IMB, maka tidak hanya beorientasi pada retribusi semata, akan tetapi terutama juga terhadap advokasi kepada masyarakat mengenai persyaratan mendirikan bangunan, sehingga sumber daya yang menangani pelayanan IMB ini harus memiliki pengetahuan yang memadai mengenai tata ruang dan teknik bangunan.

Salah satu masalah pokok yang dianggap cukup menghambat dalam pelayanan penerbitan IMB adalah proses penerbitan yang kadang dirasakan cukup lama, yaitu berkisar antara 2 sampai 4 minggu. Lamanya proses pelayanan ini terutama disebabkan oleh kemampuan sumber daya manusia yang memiliki kompetensi dalam memberikan jasa penilaian biaya pembangunan mendirikan bangunan, yang kurang memadai. Penentuan besaran biaya bangunan yang dimohonkan IMB merupakan komponen dasar dalam menilai kondisi kelayakan penerbitan IMB. Di samping itu pemahaman dan pengetahuan masyarakat terhadap prosedur memperoleh IMB, masih kurang, sehingga kelengkapankelengkapan dokumen yang diperlukan dalam proses kadang sulit dipenuhi. Sebuah pelayanan yang efisien harus bersinergi antara petugas pelayanan dengan pelanggannya, dalam arti bahwa proses pelayanan publik harus didukung oleh kedua belah pihak.

Dari pengamatan yang dilakukan, menunjukkan salah satu kesulitan pelayanan IMB adalah persyaratan gambar spesifikasi bangunan yang dimohonkan IMB yang kadang tidak memenuhi syarat ketentuan arsitektur dan civil engineering, sehingga menyulitkan stakeholders penilai untuk memberikan layanan yang cepat dan tepat.

Kebijakan penerbitan IMB adalah kewenangan pemerintah yang telah melekat aspek jasa pelayanan (unsur retribusi) di dalamnya, tentu bahwa masyarakat sebagai pelanggan atas jasa itu haruslah memenuhi aspek kualitas layanan yang dapat memuaskan masyarakat, baik terhadap kemampuan petugas pelayanan maupun terhadap jaminan (legalitas) layanan serta hadirnya petugas pelayanan yang memberikan empaty serta respons yang memuaskan masyarakat.

Tidak ekonomisnya dan tidak efektifnya pelayanan yang dapat diberikan pemerintah dalam pelayanan Izin Mendirikan Bangunan merupakan akumulasi dari masih belum memadainya kemampuan sumber daya manusia. Berkaitan dengan hal itu, pada dasarnya efisiensi dan efektifitas pelayanan pada masyarakat sangat bertumpu pada kesiapan dan kemampuan sumber daya manusia yang menjadi petugas pelayanan, baik dalam arti kecakapan dan keterampilan melayani, maupun sikap perilaku. dan motivasi dalam memberikan pelayanan. Oleh sebab itu sangat penting membangun sumber daya manusia yang handal dalam memberikan pelayanan terbaik berdasarkan prinsip efisiensi, ekonomis, transparansi, dan berkeadilan.

Saat ini, disadari bahwa profesionalisme aparatur pemerintah pada umumnya masih mendapat sorotan yang tajam dari masyarakat, terutama karena sikap pengabdiannya yang rendah, sebagai akibat kemampuan dan motivasi yang 
rendah. Hal ini dapat dilihat pada intansiintansi pelayanan masyarakat, saat ini masih sering dijumpai adanya keluhan masyarakat terhadap kemampuan pelayanan yang diberikan oleh aparatur, baik terhadap prosedur-prosedur pelayanan, lamanya pelayanan serta keputusan-keputusan dalam pelayanan yang tidak dapat dilakukan secara efisien dan efektif.

\section{TINJAUAN PUSTAKA}

\section{Sumber Daya Manusia}

Sumber daya manusia pada dasarnya adalah merupakan salah satu faktor yang sangat penting di dalam suatu organisasi, baik organisasi publik maupun swasta, karena manusia yang merencanakan sampai mengawasi pelaksanaan kegiatan dalam organisasi. Di mana manusia yang dimaksud haruslah cukup jumlahnya sesuai kebutuhan serta memiliki keterampilan yang memadai sesuai tuntutan tugas-tugas dalam organisasi. Menurut Handoko (2003:233) dalam bukunya manajemen Personalia dan sumber daya manusia mengatakan bahwa"Sumber Daya Manusia adalah orang-orang yang memberikan tenaga, bakat, kreatifitas, dan usahausahanya kepada kegiatan organisasi."

Lebih luas lagi Hasibuan (1994:10) mengemukakan bahwa; Manajemen Sumber Daya Manusia adalah ilmu dan seni mengatur hubungan dan peranan tenaga kerja agar efektif dan efisien membantu terwujudnya tujuan perusahaan, karyawan dan masyarakat. Dengan demikian, manajemen SDM dalam arti pendayagunaan sumber daya manusia adalah tanggung jawab semua manajer atau pimpinan yang mempunyai dan harus membawahi bawahan. Mengingat peranan aparatur yang begitu dominan dalam pelaksanaan tugas-tugas umum pemerintahan dan pembangunan seiring dengan adanya tuntutan perkembangan pembangunan yang makin cepat dan kompleks, maka menuntut kualitas aparatur yang memadai dalam arti sikap, keterampilan, kemampuan, profesionalisme yang tinggi agar pelaksanaan tugas dapat berjalan secara efektif dan efisien.

\section{Kualitas Pelayanan}

Goetsch dan Davis, dalam LAN (2003;17) mendefinisikan kualitas pelayanan sebagai suatu kondisi dinamis yang berhubungan dengan produk, jasa, manusia, proses dan lingkungan yang memenuhi atau melebihi harapan. Kualitas pelayanan juga diartikan sebagai sesuatu yang berhubungan dengan terpenuhinya harapan / kebutuhan pelanggan, di mana pelayanan dikatakan berkualitas apabila dapat menyediakan produk dan jasa (pelayanan) sesuai dengan kebutuhan dan harapan pelanggan.

LAN (2003;17), mengatakan bahwa kualitas pelayanan dapat dilihat dari berbagai sudut. Jika dilihat dari sudut pandang konsumen, maka kualitas pelayanan selalu dihubungkan dengan sesuatu yang baik/prima (excellent). Jika kualitas pelayanan dipandang dari sudut "product based", maka kualitas pelayanan dapat didefinisikan sebagai suatu fungsi yang spesifik, dengan variabel pengukuran yang berbeda-beda dalam memberikan penilaian kualitas sesuai dengan karakteristik produk yang bersangkutan. Kualitas pelayanan jika dilihat dari sudut "user based, maka kualitas pelayanan adalah sesuatu yang diinginkan oleh pelanggan atau tingkat kesesuaian dengan keinginan pelanggan. Sedangkan, jika dilihat dari "value based", maka kualitas pelayanan merupakan keterkaitan antara kegunaan atau kepuasan dengan harga.

\section{METODE PENELITIAN}

Lokasi penelitian adalah Kantor Pelayanan Terpadu Kabupaten Jeneponto. Alasan pemilihan lokasi penelitian yakni karena Sekretariat Daerah Kabupaten Jeneponto mempunyai tugas menyelenggarakan sebagian tugas pokok desentralisasi dan dekonsentrasi 
pemerintah, terutama dalam memberikan pelayanan kepada masyarakat. Sedangkan Tipe penelitian yang digunakan adalah metode kualitatif; oleh Sugiyono (2001) disebutnya sebagai penelitian naturalistik, yaitu metode yang digunakan untuk meneliti pada kondisi objek yang alami, karena peneliti adalah sebagai instrumen kunci. Pengumpulan data dilakukan secara trianggulasi (gabungan), data yang dihasilkan bersifat deskriptif. Hasil penelitian kualitatif lebih menekankan makna daripada generalisasi. Menurut Bogdan dan Taylor (1993), metode kualitatif menunjuk kepada prosedurprosedur riset yang menghasilkan data kualitatif; ungkapan-ungkapan atau catatan orang itu sendiri atau tingkah laku mereka yang terobservasi. Pendekatan ini, mengarah keadaan objek penelitian secara utuh (holistik).

Informan dalam penelitian ini adalah masyarakat pelanggan yang pernah mendapatkan pelayanan IMB di Kantor Pelayanan Terpadu Jeneponto. Jumlah informan inti yang terpilih adalah sebanyak 5 orang, yang dijumpai selama dalam penelitian yang berlangsung selama 1 bulan. Kemudian Informan dari aparatur pelayanan yang bertugas di bagian pelayanan Izin Mendirikan Bangunan pada Kantor Pelayanan Terpadu Kabupaten Jeneponto, yang berjumlah 2 orang. Teknik yang digunakan untuk mendapatkan data di lapangan yaitu: a) Wawancara, b) Observasi, c) Dokumentasi. Ditinjau dari kategori data yang digunakan, maka jenis penelitian ini adalah kualitatif deskriptip. Dalam perspektif Bogdan dan Taylor (1993: 5) jenis penelitian ini menghasilkan data deskriptif berupa kata-kata tertulis atau lisan dari orang-orang atau perilaku yang dapat teramati. Paradigma penelitian naturalistik memandang, bahwa suatu penelitian harus berdasarkan pada kondisi objek secara alami. Melihat jenis dan sifat penelitian yang alami dan fenomenal sebagai sebuah aktivitas yang sarat dengan simbol dan makna pada perilaku, maka pendekatan penelitin ini diarahkan pada kolektif (sebagai suatu sistem).

Pendekatan kualitatif deskriptip yang digunakan dalam penelitian ini adalah dilakukan secara trianggulasi, yaitu teknik pemeriksaan keabsahan data yang memanfaatkan berbagai sumber penelitian, terutama melakukan pengecekan balik derajat kepercayaan suatu informasi yang diperoleh melalui waktu dan alat yang berbeda. Hal ini dapat dicapai dengan jalan: 1) Membandingkan data hasil pengamatan dengan data hasil wawancara, 2) Membandingkan apa yang dikatakan informan secara formal dan yang dikatakan secara informal, 3) Membandingkan keadaan dan perspektif orang-orang dalam organisasi dengan situasi hasil penelitian.

\section{HASIL DAN PEMBAHASAN}

Masa kerja pegawai yang umumnya telah mencapai 10 tahun ke atas, maka seharusnya telah memiliki keterampilan memadai dalam menjalankan tugastugasnya, apalagi telah disertai dengan pelatihan-pelatihan teknis yang berkaitan dengan bidang tugasnya. Dalam penelitian tentang keterampilan pegawai, peneliti mengajukan beberapa pertanyaan, yaitu keterampilan dalam mengoperasikan sarana dan fasilitas mutakhir di Kantor, seperti komputer, dan keterampilan teknis yang berkaitan bidang tugasnya dan keterampilan dalam bekerjasama. Dengan demikian kemampuan pegawai dapat dilihat dari pengetahuan dan ketrampilan yang ada pada diri pegawai tersebut dalam menjalankan setiap tugasnya dengan baik. Modal pengetahuan dan ketrampilan tersebut pada umumnya dimiliki oleh para pegawai yang berpendidikan dan berpengalaman dalam pekerjaannya.

$$
\text { Dalam kaitannya dengan }
$$

kemampuan kerja, pengalaman juga merupakan bagian dari kemampuan yang juga tidak kalah pentingnya dengan faktor pendidikan. Karena pada dasarnya pengalaman juga merupakan potensi yang ada pada diri seseorang yang memungkinkan untuk bisa mengerjakan 
pekerjaanya. Bila pengalaman itu dihubungkan dengan pekerjaan seorang pegawai, maka pengertian pengalaman di sini lebih ditujukan pada pelajaran yang diperoleh seseorang dalam bekerja atau menekuni pekerjaannya. Bahkan asumsiasumsi pemahaman pekerjaan banyak diperoleh dari aktivitas yang berhubungan dengan seringnya seorang pegawai berhubungan dengan pekerjaan-pekerjaan yang berbeda dalam kariernya.

Dari uraian di atas dapat dimengerti bahwa orang yang memiliki masa dinas atau masa kerja tertentu, akan memiliki pengalaman tertentu pula dalam jabatan yang didudukinya. Dengan kata lain semakin lama seseorang menduduki jabatan, maka semakin banyak pengalaman yang diperolehnya dalam jabatan tersebut. Faktor pengalaman merupakan salah satu faktor pembentukan karier, bahkan dalam sistem pembinaan sumber daya manusia di Indonesia, pola karier atau masa kerja merupakan sarana pertimbangan utama untuk mengangkat dan menempatkan personil dalam susunan kepangkatan dan jabatan yang tersedia.

Hasil penelitian di atas, juga di dukung oleh pernyataan Kepala Bagian tata Usaha yang mengatakan bahwa :

Dalam hal penempatan pegawai dalam suatu jabatan, aspek pengalaman yang dilihat dari masa kerja seorang pegawai. Meskipun demikian pertimbangan masa kerja tersebut tentu juga dikaitkan dengan lamanya seseorang dalam suatu jabatan tertentu yang berkaitan dengan jabatan yang akan didukinya"(Wawancara $20 \quad$ Januari 2014)

Oleh sebab itu menurut penelitian yang dilakukan lamanya seorang petugas dalam menduduki suatu jabatan atau tugas tentu saja membentuk berbagai pengalaman-pengalaman, baik itu menyangkut pengalaman teknis maupun pengalaman non teknis yang telah membentuk kinerja (perfomance) mereka. Bahkan adanya pegawai yang ditempatkan tidak sesuai dengan pendidikannya, namun mereka dianggap mampu melaksanakan tugasnya karena pertimbangan dari riwayat pekerjaan yang telah digeluti selama ini, sehingga istilah karier dalam kepegawaian juga dipahami sebagai suatu rangkaian pekerjaan yang digeluti secara berjenjang dari pekerjaan paling rendah sampai kepada jabatan yang lebih tinggi. Oleh sebab itu penempatan pegawai dalam suatu jabatan dengan mempertimbangkan pengalamannya, merupakan bagian dari penghargaan terhadap proses karier seorang pegawai.

Masa kerja pegawai yang umumnya telah mencapai 10 tahun ke atas, maka seharusnya telah memiliki keterampilan memadai dalam menjalankan tugastugasnya, apalagi telah disertai dengan pelatihan-pelatihan teknis yang berkaitan dengan bidang tugasnya. Dalam penelitian tentang keterampilan pegawai, peneliti mengajukan beberapa pertanyaan, yaitu keterampilan dalam mengoperasikan sarana dan fasilitas mutakhir di Kantor, seperti komputer, dan keterampilan teknis yang berkaitan bidang tugasnya dan keterampilan dalam bekerjasama. Masa kerja pegawai, akan sangat berkaitan dengan perkembangan kariernya, dan karier sebagai pegawai negeri sipil merupakan karier selama hidup, dalam arti bahwa ada harapan sebagian pegawai untuk memupuk tingkat karier mereka mereka secara lebih baik agar dapat tetap bertahan atau meningkatkan tugas pokok dan tanggung jawabnya selaku pegawai negeri. Perkembangan karier yang memadai biasanya diikuti oleh perbaikanperbaikan pendapatan. Perbaikan karier dengan berpedoman pada masa kerja dan kompetensi pegawai negeri sipil, jelas membuka peluang pada pertumbuhan karier secara adil dan sehat pada pegawai itu sendiri, yang ujung-ujungnya dapat meningkatkan semangat pengabdian para pegawai itu sendiri. Keterampilan pegawai adalah merupakan modal dasar yang harus dimililiki dalam menerima suatu tugas, sebab tanpa keterampilan tidak mungkin 
dapat melaksanakan dengan baik, bahkan akan terjadi pemborosan energi bila orangorang yang diperkerjakan tidak memiliki keterampilan yang memadai.

Salah satu upaya dalam pengembangan keterampilan sumber daya manusia adalah dengan mengikutsertakan pegawai pada kegiatan pelatihan teknis. Pelatihan teknis merupakan pelaksanaan kegiatan pengembangan sumber daya arapatur untuk memberikan keterampilan atau penguasaan keterampilan di bidang teknis tertentu. Tujuan pelatihan teknis diharapkan dapat membantu pegawai dalam meningkatkan pengetahuan dan keterampilan sesuai kompetensi dan tuntutan kerja yang dihadapinya sekarang. Bagi sumber daya aparat di lingkungan Kantor Pelayanan Terpadu Kabupaten Jeneponto, pelaksanaan pelatihan teknis merupakan kegiatan yang selalu mendapat perhatian, sehingga telah banyak jenis pelatihan teknis dilakukan, terutama dalam mengantisipasi perkembangan tuntutan saman yang semakin maju, seperti penggunaan komputer sebagai sistem pengolah data, penerapan teknologi mutakhir dalam operasional pelayanan. Ada beberapa jenis pelatihan yang sering diikuti oleh pegawai, yaitu : latihan teknis fungsional bidang manajemen kepegawaian dan pelatihan teknis perundang-undangan dan konseling kepegawaian.

Pertimbangan untuk mengirim pegawai mengikuti pelatihan teknis, tentu saja lebih banyak didasarkan pada bagaimana mempersiapan para pegawai agar dapat memiliki keterampilan dan kecakapan teknis yang relevan dengan bidang tugas yang sedang dan akan dilaksanakannya. Pelaksanaan pelatihan teknis disamping dapat meningkatkan pengetahuan dan keterampilan aparatur, juga merupakan salah satu upaya untuk memperkecil kesalahan-kesalahan yang terjadi dalam pekerjaan.

Berdasarkan penelitian yang dilakukan menunjukkan bahwa umumnya pegawai yang telah mengikuti teknis merasakan adanya manfaat yang berarti bagi pengembangan pelaksanaan tugastugasnya, artinya pelatihan teknis yang didapatkan cukup bermanfaat dalam pelaksanaan tugas pokok sehari-hari. Kondisi tersebut juga diperkuat pernyataan kepala Kantor Kantor Pelayanan Terpadu Kabupaten Jeneponto, menjelaskan bahwa

“...tujuan pelatihan teknis adalah untuk memberikan pengetahuan dan keterampilan aparatur dalam pelaksanaan tugas yang dihadapinya sehingga diharapkan dengan keikutsertaan aparatur dalam pelatihan teknis dapat membantu dalam melaksanakan tugas-tugasnya serta mengurangi tingkat kesalahan yang terjadi dalam pekerjaan. Namun dalam keikutsertaan aparatur dalam pelatihan teknis tidak dapat dipungkiri masih terdapat aparatur yang masih memiliki kekurangan dan kesalahan dalam pekerjaan, sehingga pimpinan langsung pada tiap unit kerja diharapkan dapat berperan banyak dalam memberikan bimbingan, pengetahuan dan perhatian kepada aparatur yang masih kurang. Demikian pula rekan kerja yang telah mampu dan memiliki keterampilan dapat membantu rekan kerjanya. (Wawancara 20 Januari 2014).

Meskipun demikian dalam pelaksanaan pelatihan teknis, tidak harus memperhatikan latar belakang keterampilan yang dimiliki sebelumnya. Hal ini juga dinyatakan oleh Kasi Pengelolaan Perizinan dalam suatu kesempatan wawancara.

“....Keikutsertaan aparatur dalam pelaksanaan pelatihan teknis sebenarnya tidak perlu melihat dari latar belakang keterampilan setiap orang, akan tetapi tujuan daripada pelatihan teknis adalah untuk meningkatkan kinerja aparatur sehingga dengan mengikutsertakan aparatur dalam pelatihan teknis oleh karena adanya kebutuhan dalam organisasi tersebut, khususnya tuntutan dari tiap unit kerja untuk dapat memberikan pengetahuan aparatur agar dalam melaksanakan tugasnya tidak terdapat kekeliruan dan kesalahan. 
Disamping itu ada jenis pelatihan teknis yang memberikan wawasan dan keterampilan baru bagi aparatur" (Wawancara; 20 Januari 2014).

Dengan demikian pelaksanaan pendidikan dan latihan kepada para pegawai, sebagai salah satu instrumen pengembangan kemampuan pegawai adalah berjalan berdasarkan kebutuhan dan analisis jabatan serta tugas pokok yang ada di lingkungan Kantor Pelayanan Terpadu Kabupaten Jeneponto.

Ukuran keberhasilan pengembangan pengetahuan sumber daya aparatur melalui pengembangan pendidikan dan pelatihan adalah adanya perubahan pada peningkatan kinerja (perfomance) aparatur itu sendiri. Menurut Fitz (1987:188-197) dalam Swasto (2003:25), perubahan kemampuan pengetahuan, keterampilan dan sikap yang positif merupakan salah satu ukuran keberhasilan peserta latihan. Sedang ukuran lainnya adalah kinerja mereka yang diakibatkan oleh pengetahuan, keterampilan dan sikap mereka yang baru. Perubahan ini dapat diukur antara sebelum dan sesudah mengikuti pendidikan atau latihan, atau seberapa besar perubahan kemampuan seseorang setelah mengikuti pendidikan dan atau latihan dalam suatu kurun waktu tertentu.

Hasil penelitian di atas, didukung oleh pernyataan Kasi Data dan Informasi bahwa:

Untuk pekerjaan dan jabatan tertentu yang memerlukan keterampilan teknis, seperti bidang tugas pengolahan data serta bidang tugas fungsional dalam implementasi tugas KPT, maka pengembangan keterampilan teknis memang menjadi perhatian utama dalam setiap upaya pengembangan kepegawaian"(Wawancara 24 Januari 2014).

Dengan demikian meskipun masih ada pegawai merasakan kurang maksimal dalam pelaksanaan tugas-tugas secara teknis, namun hal itu telah mendapat perhatian oleh pimpinan di KPT untuk mengembangkan pegawai berdasarkan kebutuhan pekerjaan yang ada. Pengembangan kompetensi teknis tentu memberikan ruang yang lebih terarah seluruh sumber daya manusia yang ada untuk membina keterampilannya, baik dalam rangka membentuk karakteristik pribadi sebagai modal pribadi dalam mengembangkan kariernya, juga dimaksudkan agar seluruh kebutuhan terhadap penyelesaian pekerjaannya dapat berjalan sesuai harapan.

Pada dasarnya bahwa pegawai yang memiliki keunggulan tersendiri dalam hal keterampilan teknis dalam pekerjaan juga merupakan suatu bentuk aktualisasi diri yang dapat menunjukkan kelebihankelebihan tetentu dalam pekerjaan. Bahkan dengan sendirinya pegawai akan merasakan adanya pemenuhan dalam menyelesaikan pekerjaannya dengan lebih baik, bila didukung oleh keterampilan yang memadai. Kadang ada pegawai yang memang harus seedikit lebih stress bahkan kurang bersemangat bila dihadapkan pada suatu pekerjaan yang secara teknis kurang dikuasainya. Ditengah-tengah persaingan dan kemajuan teknologi yang semakin canggih, maka semakin dituntut kemampuan pegawai negeri untuk menguasai bidang tugasnya masingmasing, hal ini tentu menuntut adanya pembinaan dan pengembangan terutama dalam perluasan kecakapan dan keterampilan yang dirasa makin penting. Menyadari pentingnya pengembangan dan pembinaan pegawai kearah peningkatan mutu dan kinerja aparatur, maka Kantor Pelayanan Terpadu Kabupaten Jeneponto mengupayakan adanya peningkatan dan pengembangan bidang kepegawaian secara terus menerus dan menyesuaikan dengan kebijaksanaan pengembangan karier pegawai pada Kantor Pelayanan Terpadu Kabupaten Jeneponto. Sebagai salah satu organisasi birokrasi pemerintahan, maka kegiatan yang paling nyata dan menonjol adalah pelaksanaan pendidikan dan latihan bagi pegawai negeri sipil. Bila dikaitkan konsep teori yang telah diajukan pada uraian 
sebelumnya sebagaimana dikemukakan Martin (2002: 152), bahwa "seorang pegawai dapat dikatakan memiliki kompetensi yang memadai bilamana terdapat kemampuan pengetahuan (knowledge), keterampilan (skill) dan atribut personal yang berhubungan dengan sikap prilaku. Oleh sebab itu membangun seorang pegawai harusnya bermuara pada ketiga harapan di atas.

\section{Diklat Kepemimpinan (Dikltapim)}

Diklat kepemimpinan atau sering juga disebut sebagai diklat struktural, yaitu pendidikan dan latihan yang dilakukan untuk memberikan bekal pengetahuan mengenai kepemimpinan dalam jabatannya. Oleh sebab itu hampir dipastikan bahwa semua pegawai yang telah diikutkan dengan kursus ini, merupakan individu pegawai yang memang memenuhi syarat untuk suatu jabatan struktural / eselon tertentu, seperti Suspim Tingkat IV, maka umumnya dipersiapkan bagi jabatan eselon IV.

\section{Tabel 1 Keadaan Pegawai Kantor Pelayanan Terpadu Kabupaten Jeneponto yang Pernah Menikuti Diklatpim}

\begin{tabular}{|l|l|c|}
\hline No. & Jenis Diklat Struktural & Jumlah \\
\hline 1. & Diklatpim I & - \\
\hline 2. & Diklatpim II & 1 \\
\hline 3. & Diklatpim III & 4 \\
\hline 4. & Diklatpim IV & 8 \\
\hline \multicolumn{2}{|c|}{ Jumlah } & 13 \\
\hline
\end{tabular}

Sumber : Data sekunder, 2014

Berdasarkan tabel 1 tersebut di atas, maka dapat dilihat responden yang diteliti, ternyata diklatpim yang telah diikuti telah sampai pada diklatpim II, dan kursus yang paling banyak diikuti adalah diklatpim III dan IV, hal ini tentu saja berkaitan dengan struktur jabatan yang ada, di mana semakin tinggi jabatan semakin mengerucut (model piramida), yaitu pada jabatan yang lebih rendah tersedia banyak formasi jabatan, sehingga banyak pegawai berpeluang kearah itu.

Hasil penelitian yang dilakukan menunjukkan bahwa peluang bagi keikut sertaan pegawai untuk Diklatpim adalah sangat terbuka bagi semua pegawai berdasarkan tingkat kompetensi mereka, dalam arti bahwa semua pegawai yang memang memenuhi syarat untuk itu diberikan kesempatan yang sama tanpa memandang latar belakang yang bersifat subjektif untuk mengikuti diklatpim pada semua jenjang yang tersedia, berdasarkan hasil analisis jabatan yang telah dilakukan.

\section{Diklat Teknis}

Salah satu upaya dalam pengembangan sumber daya manusia adalah melalui pengembangan pegawai dengan mengikutsertakan pegawai pada kegiatan pelatihan teknis. Pelatihan teknis merupakan pelaksanaan kegiatan pengembangan sumber daya arapatur untuk memberikan keterampilan atau penguasaan keterampilan di bidang teknis tertentu. Tujuan pelatihan teknis diharapkan dapat membantu pegawai dalam meningkatkan pengetahuan dan keterampilan sesuai kompetensi dan tuntutan $\mathrm{k}$ erja yang dihadapinya sekarang.

$$
\text { Peningkatan kemampuan para }
$$

pegawai tersebut, juga dinyatakan dalam bentuk pelaksanaan tugas yang mampu mencapai target-target pekerjaan dalam suatu sub tugas tertentu, di mana umumnya pegawai mampu melaksanakan dan menyelesaikan target tugas sesuai harapan.

Dari hasil wawancara penulis dengan salah satu informan yaitu Kepala Bagian tata Usaha menanggapi bahwa: "Pada dasarnya lama atau tidaknya waktu yang digunakan pegawai dalam menyelesaikan tugas-tugas yang diberikan, memang berkaitan dengan keterampilan yang dimiliki seseorang. Menurut saya keterampilan tersebut menyangkut ketelitian, keahlian, atau kemampuan menguasai suatu pekerjaan, misalnya seseorang yang ahli dibidang ekonomi 
maka jika diberi pekerjaan perhitungan atau sebagai bendahara maka dia mampu menyelesaikan pekerjaan tersebut dengan cepat karena dia memiliki keterampilan di bidang itu. Atau misalnya pegawai yang berprofesi sebagai sekretaris, jika dia mampu menguasai teknologi komputer maka kemungkinan pekerjaan seperti membuat surat atau laporan dapat diselesaikan dengan cepat karena dia memiliki keterampilan menggunakan sarana yang ada. Jadi keterampilan itu memang sangat diperlukan dan dibutuhkan pada setiap pegawai.(Wawancara 25 Januari 2014).

Saat ini rata-rata instansi pemerintahan apalagi swasta pada saat merekrut pegawai sangat memperhatikan keahlian seseorang, olehnya itu selain memiliki latar belakang pendidikan sarjana juga mempertimbangkan keahlian yang mereka miliki, misalnya memiliki sertifikat komputer, bahasa inggris, dll. Atau setingkat SLTA kejuruan yang memiliki keahlian pada bidang tertentu yang dipersiapkan menjadi tenaga yang siap pakai dan telah mengikuti trainingtraining. Mengapa keterampilan begitu penting mengingat kita membutuhkan pegawai yang dapat bekerja secara efektif dan efisien apalagi saat ini pemerintah khususnya aparatur berupaya memberikan pelayanan yang prima kepada masyarakat.

Upaya pengembangan keterampilan pegawai, pada dasarnya bahwa pendidikan dan latihan bukan satu-satunya cara, akan tetapi juga dilakukan melalui usaha manajemen kepegawaian secara keseluruhan, termasuk melalui cara perputaran (turnover) pegawai dalam pekerjaan, sehingga pegawai yang ada akan mengalami penambahan pengalaman dalam bekerja. Berdasarkan penelitian yang dilakukan proses perputaran pegawai dalam pekerjaan, memang dilakukan tidak begitu efektif, bahkan terlihat masih banyak pegawai yang berada pada satu tempat pekerjan dalam waktu yang cukup lama, sehingga menimbulkan kejenuhan bagi pegawai, sert perluasan keterampilan pegawai juga tidak memadai.

Terjadinya perputaran pegawai dalam suatu organisasi memungkinkan para pegawai untuk menambah wawasan pekerjaan, juga dapat memberikan penyegaran-penyegaran dalam bekerja karena adanya suasana baru yang dapat dirasakan oleh pegawai tersebut.

Perkembangan Sumber Daya Manusia, akan mendukung pencapaian tujuan organisasi, serta merupakan pemenuhan kebutuhan pegawai untuk bisa menempati jenjang karier yang lebih tinggi, yang berupa kenaikan pangkat atau jabatan disamping pencapaian kebutuhan dasar lainnya. Peningkatan keterampilan maupun keahlian pegawai akan memudahkan pencapaian tujuan pegawai dalam menduduki posisi tertentu. Kenaikan pangkat atau jabatan yang lazim disebut promosi pegawai menunjukkan kepada pemberian kesempatan bagi pegawai untuk dapat lebih baik daripada keadaan sebelumnya. Pada hakekatnya keinginan untuk maju dan mencapai keadaan lebih baik merupakan kebutuhan dasar bagi setiap manusia untuk memperbaiki kualitas kehidupannya. Pemuasan keinginan atau kebutuhan ini juga sekaligus sebagai tantangan dalam pencapaian tujuan individual, sehingga di antara pegawai terjadi persaingan.

Keterampilan ditunjukkan dalam menyelesaikan persoalan dan beban tugas yang diberikan dengan penuh rasa tanggungjawab, memiliki inisiatif dan kesediaan dalam mendukung program kerja. Ketarampilan di sini tidak cukup hanya keterampilan teknis saja, tetapi juga meliputi keterampilan dalam menetapkan strategi memberikan pelayanan serta keterampilan dalam berkomunikasi dengan baik terhadap masyarakat yang dilayaninya. 


\section{KESIMPULAN}

Sumber daya manusia dalam hal ini aparatur dalam pemberian pelayanan kepada masyarakat di Kantor Pelayanan Terpadu Kabupaten Jeneponto memiliki kualitas yang cukup memadai, yang ditandai dengan tingkat pendidikan umumnya S1 dan S2, serta didukung oleh pengembangan pengetahuan dan keterampilan baik melalui pendidikan lanjutan maupun pendidikan dan latihan.

\section{DAFTAR PUSTAKA}

Bogdan, R., dan Taylor J S. (1993). DasarDasar Penelitian Kualitatif. (Terjemahan A Khozin Afandi) Surabaya, Usaha Nasional.

Handoko, T. Hani, (2003). Manajemen Personalia \& Sumber Daya Manusia, BPFE, Yogyakarta

Hasibuan, Malayu, S.P., (1994). Pengantar Manajemen, Haji Mas Agung, Jakarta

Lembaga Administrasi Negara (LAN), 2003, Penyusunan Standar Pelayanan Publik, Jakarta.

Martin, H, (2002), Kepemimpinan dan Motivasi, Balai Pustaka, Jakarta

Sugiyono, (1999). Metode Penelitian Administrasi, Alfabeta, Bandung.

Swasto, B.(2003). Pengembangan Sumber Daya Manusia, Bayumedia, Malang. 